\title{
PROBLEMATICS OF SOCIAL WELFARE REALIZATION IN UKRAINE
}

\author{
Antoniv Anastasiia ${ }^{1}$, Shapovalova Tetiana ${ }^{2}$ \\ Lviv Polytechnic National University, Lviv, Ukraine \\ ${ }^{1}$ Student of bachelor program «Social welfare» of Department of Sociology and Social Work \\ ${ }^{2}$ Candidate of Economic Sciences, Associate Professor of Department of Sociology and Social Work
}

Background: Nowadays, combating poverty and ensuring an acceptable standard of living for citizens are priority tasks for government of any country. Constructive social policies, productive preventive measures, timely identification of obstacles and effectiveness of social assistance systems add significant value and are effective protection methods keeping in check social risks. Recent developments, such as the integration of Ukraine into European structures, have led to reform on multiple fronts to meet updated standards of development. The field of social welfare is of particular interest. Nevertheless, the realization of social welfare in Ukraine remains to be fraught with challenges despite changes and reforms in the field of national level social politics.

Purpose: analysis of the actual social welfare system in Ukraine, identifying and outlining major weaknesses in its implementation.

Methods: The approach of this study is based on general scientific methods, including the methods of analysis, synthesis and comparison. These were applied to study fundamental works, monographs and publications on the formation of the modern social welfare system in Ukraine. A historical approach was used to generate an overview of changes in the Ukrainian social security system over the last decades. The content analysis method was applied to interpret key publications on the formation and development of social protection.

Results: Challenges pertaining to the realization of social welfare in Ukraine include three main aspects. These are discrepancies and contradictions of current legislation, lack of direct social assistance and a decrease of citizen social activity. Legislative and enforcement-related changes need to be implemented for the social security system of Ukraine to be effective at safeguarding citizens against the threat of social risks.

Conclusion: It's important to identify social welfare system's challenges in order to prevent their possible occurring, quickly and decisively, as well as to secure effective realization of social programs. Understanding of the problematics allows to coordinate actions efficiently and to choose tailored methods to improve realization of social welfare system in Ukraine.

Keywords: social welfare, targeted social assistance, problematics of social welfare realization, social welfare, social assistance, social security system.

Як показує історичний досвід, реалізація соціального забезпечення в Україні в першу чергу стикнулась 3 економічними проблемами. Відтак, економічні кризи спричинили несприятливі умови для державного фінансування у сферу соціальної політики, а також соціальне забезпечення i захист населення загалом. Проте, проблематика реалізації соціального забезпечення в Україні включає не тільки фінансові фактори. Фахівці виділяють такі три основних аспекти, які унеможливлюють ефективну реалізацію соціального забезпечення, а саме: невідповідність та суперечність чинного законодавства, відсутність адресності допомоги та зменшення соціальної активності населення.

Масив чинного законодавства у галузі соціального забезпечення та захисту населення складається із законодавчих актів, які є часом суперечливими та неактуальними на сучасні реалії. Окрім того, держава бере на себе додаткові зобов'язання, які не є передбаченими Конституцією України чи міжнародними актами, не маючи необхідні ресурси для їх реалізації. Збільшення обсягу ратифікації міжнародних договорів, які приймаються без одночасного внесення змін до чинного законодавства зумовлюють неефективну боротьбу з соціальними та економічними проблемами, відповідно, це створює негативний імідж країни серед міжнародного товариства (Гурт, 2009). 
Неефективний розподіл матеріальної соціальної допомоги між отримувачами це ще одна проблема на шляху до продуктивної реалізації системи соціального забезпечення. На думку багатьох науковців, громадських та політичних діячів, адресна соціальна допомога $\epsilon$ вирішенням більшості соціальних проблем. Адресність - принцип ефективного призначення та розподілу соціальної допомоги, що покращує використання коштів, які виділені на цілі соціального забезпечення шляхом спрямування допомоги цільовим категоріям населення, а саме особам, що знаходяться за межею бідності. Такий інструмент є типовим для боротьби 3 бідністю в межах наявного бюджету програми соціальної допомоги або для досягнення заданого ефекту за найменших витрат державних коштів (Богданова, 2011).

Варто зазначити, що впровадження адресності в системі соціального забезпечення допоможе: сформувати логічне обмеження кількості пільговиків, здійснити перегляд та нормування самої системи нарахування соціальної матеріальної допомоги задля унеможливлення необумовленого використання пільг, розробити єдину базу даних отримувачів соціальної допомоги та запровадити систему стандартизації соціальної допомоги, що удосконалить механізм управління соціального захисту та вплине на іiї результативність (Піскун, 2013).

Для ефективної реалізації соціального забезпечення населення необхідний стабільний та високий рівень соціальної активності громадян. Соціальне матеріальне забезпечення окремих категорій населення без заходів реінтеграції в суспільство можна розглядати як чинник занепаду соціальної активності отримувачів такої допомоги. Причиною такого занепаду є те, що внаслідок зростання доходу отримувача, він втрачає право на соціальну допомогу, оскільки більшість 3 них є пов'язані 3 певним рівнем доходів. Міжнародні стандарти соціального забезпечення громадян включають заходи реінтеграції в суспільство: коли настає соціальний ризик, особа отримує соціальну допомогу від держави сукупно з реабілітаційними заходами та допомогами. Проте, попри цілу низку ратифікованих міжнародних документів та стандартів, в Україні заходи реінтеграції людей в суспільство та збереження їхньої соціальної відповідальності та активності залишають бажати кращого.

Система соціального забезпечення в Україні пройшла довгий шлях удосконалення та змін, проте в питаннях іiі реалізації ще залишаються гострі проблеми. Виділивши основні проблеми реалізації соціального забезпечення в Україні, ми розуміємо, що вони всі $є$ частково взаємозалежними та причинно-наслідковими, проте розуміння самих проблем дає змогу подальшого їх ефективного вирішення. Щоб подолати проблематику реалізації потрібно створити прозорість, координованість та гласність щодо фінансування системи, забезпечення адекватної винагороди за працю, заохочування соціальної відповідальності та активності, введення в систему належних заходів щодо реінтеграції осіб в суспільство, які потрапили в складні життєві ситуації та підвищення ефективності у виконанні взятих на себе зобов'язань у сфері вдосконалення державної системи соціального забезпечення та іiі інтеграції у європейську систему та міжнародну, зокрема.

\section{Список використаних джерел:}

Богданова, О. О. (2011). Адресна соціальна допомога - складова соціальної політики. Фінансовий простір, 4, 66-70. Retrieved from https://fp.cibs.ubs.edu.ua/index.php /article/view/145/141

Гурт. (2009). Актуальний стан та проблеми діючої системи соизального захисту в Украӥні. Retrieved from https://gurt.org.ua/news/recent/3803/

Піскун, К. В. (2013) Адресність соціальної допомоги як напрям покращення методики планування видатків соціального призначення. Соціально-економічні проблеми $i$ держава, 1 (8), 212-221. Retrieved from http://elartu.tntu.edu.ua/handle/123456789/2274

\section{References}

Bohdanova O. (2011) Adresna sotsialna dopomoha yak skladova sotsialnoi polityky [Direct social assistance as a component of social policy], Finansovyi prostir - Financial space, 4, 66-70. Retrieved from https://fp.cibs.ubs.edu.ua/index.php /article/view/145/141 [in Ukrainian]. 
Hurt (2009) Aktualnyi stan ta problemy diiuchoi cystemy sotsialnoho zakhystu $v$ Ukraini [Current status and problems of the existing social protection system in Ukraine]. Retrieved from https://gurt.org.ua/news/recent/3803/ [in Ukrainian].

Piskun K. (2013). Adresnist sotsialnoi dopomohy yak napriam pokrashchennia metodyky planuvannia vydatkiv sotsialnoho pryznachennia [Targeting of social assistance as a way to improve the methods of planning of social expenditures]. Sotsialno-ekonomichni problemy $i$ derzhava - Socio-Economic Problems and the State, 1 (8), 212-221. Retrieved from http://elartu.tntu.edu.ua/handle/123456789/2274 [in Ukrainian].

\section{Contact information:}

Shapovalova Tetiana Viktorivna gg39358@gmail.com

Antoniv Anastasiia Teofilivna claricemaclelen@ukr.net 